\title{
S100A12 wt Allele
}

National Cancer Institute

\section{Source}

National Cancer Institute. S100A12 wt Allele. NCI Thesaurus. Code C52258.

Human S100A12 wild-type allele is located within $1 \mathrm{q} 21$ and is approximately $2 \mathrm{~kb}$ in length. This allele, which encodes S100-A12 protein, is involved in both cell cycle progression and differentiation and may be involved in calcium-dependent signal transduction pathways. 